Article

\title{
Elizabeth Bishop and the Poetry of Meditation
}

\author{
James Matthew Wilson \\ Department of Humanities and Augustinian Traditions, Villanova University, 800 Lancaster Ave., Villanova, \\ PA 19085, USA; james.m.wilson@villanova.edu \\ Academic Editor: Kevin Hart
}

Received: 5 July 2016; Accepted: 4 January 2017; Published: 11 January 2017

\begin{abstract}
Elizabeth Bishop's poetry has won the admiration of a number of Christian poets and scholars. This essay argues that one reason for this is Bishop's subtle engagement with the work of the poet-divines Gerard Manley Hopkins and, especially, George Herbert; through their influence, she enters into the guiding western poetic tradition of the meditative lyric, which is rooted in the Platonic and Christian accounts of the human person as an image of the Triune God in virtue of the mind as a trinity of memory, understanding, and will. Bishop practiced poetry as a moral act open to a divinity it cannot account for or even name, but traces of whose significance run through the world her poems depict. By considering her work, and her poem "The Weed" in particular, in the context of Herbert, the historical studies of Louis L. Martz, and the literary theory of Yvor Winters, we see that Bishop the unbeliever cannot properly be understood as a "secular" poet, but as one who recognizes the meditative lyric as a way of arriving at understanding of a truth that transcends us.
\end{abstract}

Keywords: Elizabeth Bishop; Yvor Winters; Louis L. Martz; Meditative Lyric; the Secular; George Herbert; Christian Platonism; Augustine; modern poetry

\section{Introduction}

Over the last few years, I have noticed that a number of Christian poets and scholars of Christianity seem to harbor a particular affection for the work of Elizabeth Bishop, and that they do so for reasons evidently tied to their religious beliefs. I do not mean by this the oft-cited admiration of Dana Gioia for Bishop. Although Gioia may now be America's best-known living Catholic poet, his work in prose and verse has, until recently [1], shied away from any such title, and indeed he has written that Bishop influenced him chiefly in her unwavering commitment to the self-effacement of the artist engaged in craft, in making a good poem. ${ }^{1}$ I think rather of essays and books, such as those by Cheryl Walker [4], Laurel Snow Corelle [5], and Elisa New [6], which, although never seeking to baptize Bishop by the force of interpretative will, take the poet's Calvinist childhood and anguished agnosticism alongside her poems as material for serious theological and devotional meditation. ${ }^{2}$

Given the trajectory of Bishop's life, which proceeds at a slow, grinding pace down a slope of uncontrolled, addictive, and self-destructive appetites, this has always surprised me, though perhaps it should not ([4], p. 21). Bishop's contemporaries to whom she is often likened, Robert Lowell [7]

1 Gioia has published two essays on Bishop. The first offers an appreciation of the poet as an example of the poet's reticent duty to craft in an age characterized by indulgent (confessional) self-possession [2]. The second, written many years later, attempts to account for the rise of this once minor poet to "major" or canonical rank in the opinion of contemporary critics and lay readers [3]. The first describes the role as mentor and inspiration for Gioia's own work, while the second acknowledges the role of gender studies in the increased interest in her work while attempting to show that the poetry itself transcends the passing sociological or historical attention that has been paid to her.

2 Corelle and New seek chiefly to show that Bishop's rich and devout Protestant background continued to be a source of inspiration and anxiety throughout the course of her career ([5], pp. 1, 39). Walker is more provocative and ambitious. Her fine literary study seeks to step beyond contemporary conventions of criticism to explore Bishop's work as a stimulus to Christian devotion. 
and John Berryman [8], lived at least equally unhappy lives; and yet, through the work of sensitive critics, including New, and their biographer, the Catholic poet Paul Mariani, they have taken their places among the more riveting dramas of the Catholic intellectual revival that occupies a central place in Twentieth-Century American literary history. ${ }^{3}$ Furthermore, in deliberate contrast with Lowell, Bishop's poems eschew anguished and sometimes vitriolic expressions of personal apostasy-indeed, they programmatically if inconsistently avoid the personal, in the sense of "confessional." The restraint, the austerity, the third-person objectivity that characterize the majority of Bishop's poems not only eliminates this likely obstacle for her Christian readers; these very hallmarks-developing an approach to poetry and manners she found and admired in her mentor, Marianne Moore-are what give her work its distinctive place in the poetry of the last century ([5], pp. 4, 14).

Is there any other modern poet whose discipline in verse so absolutely dominates, conceals, and yet also responds to an unruliness in everyday life? I can think of a few comparable examples, but Bishop nonetheless stands out for her peculiar achievement in this regard. I would like to propose Bishop as one of the consummate modern practitioners of one of the leading traditions of lyric poetry in English-the poetry of meditation [10]. And I suggest that her work adds a notable, if limited, new dimension to it; it is a dimension that Bishop herself may not have appreciated and whose implications she may well have denied, but it is also one which, I propose, helps explain the abiding interest Christian readers, scholars, and poets have taken in her work.

The roots of the meditative lyric tradition are decisively Christian, as Louis L. Martz proposed decades ago in his ground-breaking study, The Poetry of Meditation [11]. Bishop maintains and develops its conventions through a close but uneven engagement with those roots-above all, as they are expressed in the devotional poetry of George Herbert and Gerard Manley Hopkins [12-15]. As a nonbeliever she nonetheless found resources in the devout Christian poetic of those two predecessors and she adapted their meditative practices to an end that is less than true contemplation but more than merely what I shall call therapeutic self-reflection. In this sense, her work exhibits poetry as what the American poet and critic Yvor Winters called a moral act [16]. My intention is to consider the moral tenor of Bishop's work and its debt to and modifications of the Christian tradition of the meditative lyric as a way of explaining why Bishop has garnered the Christian audience she has. I will describe some of the meditative features found in many of her poems, but attend with specific care to her early engagement with Herbert, in her poem "The Weed," where what is most distinctively modern and apparently "secular" about Bishop's work seems also strangely tinted by her engagement with the Christian meditative lyric tradition. I shall conclude with a reflection on what it means for her meditative lyrics to be moral rather than devotional acts so as to make clear that, while they can only be called Christian insofar as they draw ambivalently on Christianity's intellectual vision and moral concerns, it does not illuminate the character of her work to call it "secular" in the familiar modern sense of the refusal of anything that transcends temporal life in this world. ${ }^{4}$ To the contrary, a central quality of her work is its often niggling suggestion that the world is informed by— "moralized" bya transcendent dimension that she continues to perceive though she has lost the faith necessary to name. Taking that suggestion seriously in turn shades how we may read her poetic career as a whole.

3 I have summarized their role in that tradition elsewhere [9].

4 The last several decades has witnessed a substantive calling into question the nature of the "secular" and the characterization of ours as a "secular" age. The work of Charles Taylor and John Milbank reveals it as a much more historically limited and yet complex and even incoherent account of the modern age than it might have appeared to a poet like Bishop in mid-century America. From Augustine forward, as Robert Markus has ably shown, Catholic thought has a clear conception of the "secular" not as what refuses to look beyond this world, but as what is simply a proper immanent concern to it. My use of the word is simpler and more familiar to the contemporary reader than these theorizations, and is conveniently defined in Rémi Brague's short essay, "The Impossibility of Secular Society" [17]. There, Brague proposes that the modern use of "secular" derives from the term used specifically to describe the Christian vision of the world as created and destined to pass away. In its modern acceptation, he contends, we use it to describe a vision of the world that takes into account only the span available for "living memory" ([17], p. 28). In this sense, to be secular means to think only in terms of what is immanent to us in space and time, i.e., in this world for about a hundred years (a century), and so to refuse to think in terms of what is spiritually or historical transcendent of that low horizon. 


\section{Bishop's Moral Forms}

While Bishop wrote a remarkable variety of poems given the small size of her oeuvre, ${ }^{5}$ the trait most obvious in her work is a close attention to the concrete (sensible or surface) details of place and character that furnish the occasion for a restrained but definite moral analysis. Recall the vivid portrayal, early in "The Moose," of a bus as it "journeys west,"

the windshield flashing pink,

pink glancing off of metal,

brushing the dented flank

of blue, beat-up enamel;

down hollows, up rises,

and waits, patient, while

a lone traveler gives

kisses and embraces

to seven relatives

and a collie supervises. ([18], pp. 158-59)

The poem begins with a catalogue of concrete but telling objects to describe but also define the "narrow provinces" where the poem is set, and slowly leads us here, to the bus's waiting, where its patience indicates that Bishop's attention to the material objects of the world does not lead her to present her surroundings as adequately apprehended once one has attended only to their physical features. She seeks, rather, to reveal how subtle and yet how complete is the mergence in experience between sensible facts and their moral significance. The eye sees the patience of a bus along with the bus itself, and while it is the lone traveler who literally says goodbye in these lines, that valediction is fulfilled or completed by the bus:

Goodbye to the elms,

to the farm, to the dog.

The bus starts. ([18], p. 159)

Other poems, such as "The Fish", "Seascape”, "At the Fishhouses", “The Armadillo", and "Arrival at Santos" repeat this procedure. They offer initial precise, impersonal description that remains at once distinct from, but continuous with, a discipline of moral analysis that typically refuses to make any pronouncements unearned by what description has actually shown, and seems to do so because that analysis is already embedded in the landscape of the poem. A late poem, "12 O'Clock News", shows that there is a certain playfulness to her procedure. Bishop's abandonment of the Protestant Christianity of her family was clearly provoked by a resistance to compulsory beliefs of any kind, and her poetry in consequence largely resists committing itself wholly to the moral dimension it discloses. As Corelle notes,

For Bishop the implicit certitude of any system was anathema to her remarkably consistent approach to life and literature, which was, broadly speaking, to remain wide open to possibility and at the same time to resist being conscripted-into any faith, institution, or unilateral concept. ([5], p. 5)

We shall see that this description of Bishop as maintaining a dogmatic adherence to the possible probably comports neatly with her own self-understanding. But a meaningless phrase like "unilaterial concept" encourages us to think there is something inadequate about this understanding; I will try to

5 Bishop published ninety-five poems in her lifetime. While she left a great deal of poetry unpublished, it has so far met with mixed evaluation from scholars ([12], p. 47; [5], pp. 16-17). 
provide a more precise one below. Nonetheless, let the point stand that Bishop's poetry often depicts the material world as genuinely rife with moral significance even as some poems simultaneously entertain and resist that depiction by rendering it a matter of poetic play or, more often, by simply ignoring the questions such a depiction raises.

One of her best known poems, "The Fish", allows the encounter with a morally, perhaps even divinely, "charged" world to unfold in a powerful way. ${ }^{6}$ There, Bishop provides an exacting, indeed exhaustive, description of a fish the poet has caught and held "beside the boat / half out of water, with my hook / fast in a corner of his mouth" ([18], p. 33). As she discerns the scars of endurance in the fish's body, its lip and jaw, she begins to feel a "victory" over death fill up "the little rented boat," until, finally, the scales of the fish and the oil spreading across the bilge water's surface around the boat's little outboard engine turn everything "rainbow, rainbow, rainbow!" ([18], p. 34). An ecstatic phrase, it may seem, recalling moments from Genesis and the synoptic Gospels, as if the significance of the scene can appear to us only if drawn from elsewhere by way of allusion. But this misses something. The poem has an epiphany, to be sure, but it does not descend from elsewhere or above. Rather, it emerges from below, as fact gives up its meaning. The repeated words are restatements of what was already present but seen for the first time in full significance. Bishop's poems always seem to respect what is, but they discern not just ontological or intelligible significance, as much modern poetry does, but also the moral imperatives-the oughts—embedded in the world as we come to know it. ${ }^{7}$

One of Bishop's most accomplished poems, "At the Fishhouses," has sometimes been accused of violating the hard-earned objectivity of its early lines with its more self-reflective concluding passage. This charge does not hold up. It is, however, worth noting, because it indicates her normal practice of beginning in the concrete and arriving at abstract and moral observation only thereafter. It is also worth answering in order to show still further how a Bishop poem operates with its subtle movement from impersonal description to moral perception without the latter ever violating our sense of what is already present in the former. The first sixty-six of its eighty-three staggered, free verse lines provide a restrained and sustained description of a cold evening on the docks of a northern fishing village:

\author{
Although it is a cold evening, \\ down by one of the fishhouses \\ an old man sits netting, \\ his net, in the gloaming almost invisible, \\ a dark purple-brown, \\ and his shuttle worn and polished. ([18], p. 50)
}

The scene slowly unfolds through alternations of obscure and glistening colors (the purple-brown of the net which contrasts with the scattered silver of the sea, tossed lobster pots, glimmering masts, and benches, and above all the cream of scales in the herring tubs), and of sobering and awakening

6 As Lafford notes, Hopkins' account of the world as "charged with the grandeur of God," and that "charge" as the intelligible mystery of signs present within the landscape as "inscape," clearly informs Bishop's depiction of the moral form of the world in her own poems ([15], pp. 253, 262). Cf. Walker ([4], p. 132).

7 See Wilson, "The Realism of Helen Pinkerton" [19] and Wilson, "Brian Coffey, Jacques Maritain, and the Recovery of the 'Thing'" [20] for accounts of "ontological significance" as represented in modern poetry. Moore and Bishop are distinctive because of their unfettered concern with the didactic or moral significance to be found in things. The "is/ought" distinction I use here to describe that significance is of course Hume's law [21]. I am proposing that the "impoverished" mechanistic view of causality (and of reality as a whole; Cf. Jenkins [22] and Schindler ([23], pp. 129-62) articulated by Hume is the one Bishop might expect us to assume and the one that her poetry resists by describing the world around us as bearing intrinsic moral significance. We could account for the world she depicts in other, more satisfactory, ways than that allowed by the vocabulary of British empiricism, but I am specifically trying to bring out the way her poetry assumes but then moves against that vocabulary. She is one of many modernist poets who senses that the supposed rationality of "secular" modernity is an impoverished one that makes the imaginative tropes of poetry to appear as residuals of myth and as irrelevant distortions of the actual world, and yet who goes in search of ways to express the spiritual significance of things as a possible literal reality. What her contemporaries take as mere figurative language she plays with or hints at as disclosing something more. To perceive this, it is easiest to take Hume's empiricism as expressive of the typical "secular" viewpoint against which she writes. 
sensations (the stiffening cold contrasted with the air, which "smells so strong of codfish / it makes one's nose run and one's eyes water" [18], p. 50). The clothing of the fisherman is described, as are the rituals of work that at other times transpire in this presently still scene. The frequent sighting of a seal is noted, along with the poet's serenading him with Baptist and other hymns. All this comes to us in prosaic and discursive fashion, as if jotted down with no criterion of selection other than the effort to omit nothing that may be observed.

But then, Bishop's persona, which has entered the scene only enough to record that she speaks and smokes a cigarette with the old man, who "was a friend of my grandfather" ([18], p. 51), and to sing to the seal, emerges from the itemized scene to assume a position of authorial reflection. This, in turn, prompts her to address the reader in the second person:

I have seen it over and over, the same sea, the same, slightly, indifferently swinging above the stones, icily free above the stones, above the stones and then the world. If you should dip your hand in, your wrist would ache immediately your bones would begin to ache and your hand would burn as if the water were a transmutation of fire that feeds on stones and burns with a dark gray flame. If you tasted it, it would first taste bitter, then briny, then surely burn your tongue. It is like what we imagine knowledge to be: dark, salt, clear, moving, utterly free, drawn from the cold hard mouth of the world, derived from the rocky breasts forever, flowing and drawn, and since our knowledge is historical, flowing, and flown. ([18], p. 52)

The claims Bishop makes here, culled from the sensation of water so chill it burns, are bolder than the quiet suggestion in "The Moose" that a bus might wait with patience. But the last line of the poem provides us with a justification for her movement from material detail to moral significance. Our knowledge is historical, it is derived from and bound to our temporal experience, and, as such, it also informs that experience and bears within it a trace of experience's flux. The sea's flow is like knowledge; but also, knowledge is like the sea's flow. We expect knowledge to be "cool" and disinterested as an ideal beyond the "heat" of time, but Bishop shows that such knowledge is already pregnant with figurative significance: metaphor is required to reveal the real analogies between things. Thus, precise descriptions do not, in their exactitudes, sever meaning from experience through an unrelenting and literal empiricism that would reduce reality to sensation. They rather establish that the flux of sensation already bears within it a transcendent significance and any lasting sign-the object of knowledge-will find expression in terms of, in relation to, the flux. Familiar distinctions of "fact" and "value" collapse, because what goes by the name of "value" is at once already within every "fact" - that is how we come to perceive it—and beyond it, such that it is something we can really come to know, in the sense of having a permanent or lasting idea.

"At the Fishhouses" does this in a peculiar manner typical of Bishop's poetry. The substance of the poem's final line is that all knowledge passes away, that it is part of the flux that it comes to know, as the knower no less than the known is "historical," one relative reality within the passage of time. It would seem to be a plain disavowal of the possibility of genuine knowledge, which we expect in some sense to stand beyond history even if it is known within it. And yet, the claim overleaps the bounds of this position with its quiet but final and universalized didacticism. It concludes by suggesting a point of view above that of the attentive, expressly subjective, first-person voice of the poem, at once admitting us into it and yet stopping before specifying its nature. The definitive claim 
with which the poem ends itself stands "above the stones and then the world," giving to the fluidity of historical experience a depth of permanent meaning. The lyric voice moves from the recording of sensation "up" to moral reflection, where the meaning of things can be judged.

From this final "transcendent" perspective, we look back upon the literal details of the poem and see that Bishop has continuously worked a contrast between the darkness of depth and significance and the "creamy iridescent" surfaces of the world ([18], p. 51). "All is silver" and "opaque" on the surface, Bishop writes, drawing our attention twice to the "layers of beautiful herring scales," which are the "principal beauty" of those "unnumbered fish" caught up from the depths of the sea ([18], p. 51). Such beauty is, of course, the waste left behind by the cleaning of fish in preparation for selling the edible interior "depths" of their bodies at market. The silver shine of surface has thus drawn the poet to reflection on what it conceals; appearance draws her toward reflection on the depths of historical and intellectual significance. Where the fish come from-the "Cold dark deep" of the interior ([18], p. 51) - is the inevitable destination of a poem that seems, at its start, concerned only as it were with the silver skin of things.

The poem leaves what the true meaning of this world is vexed with uncertainty, however. The seal listens to her Baptist hymns "as if it were against his better judgment" ([18], p. 52), so that we have gestures toward Christian devotion and toward a natural world anthropomorphized and so rendered morally intelligible to us, but both are comically canceled by the seal's "skepticism." The whole scene is rimmed behind the poet by a line of "dignified tall firs" ([18], p. 52). Like the seal, these too are graced with a kind of moral significance, as the poet associates them with Christmas-"a million Christmas trees stand[ing] / waiting for Christmas" ([18], p. 52). But such a Christian association has a deflated and unbelieving undertone. So, finally, the knowledge drawn from the sea, the analogy between the sea and knowledge, at the poem's moment of greatest seriousness of tone and subject, seems like a moment of incarnation-knowledge coming into the world after the fashion of the Word (logos) made flesh. Like the Christ child, it seems even "derived", if not from human, at least from "rocky breasts" ([18], p. 52). And so we have an image of transcendent order becoming one with the flow of history, and of the depths of the sea with eternal truth. The poem seems to give us these images of skin becoming depth, literal detail becoming literal significance, and then to stop short and undercut them. The poem as a meditation leads the poet on an interior journey through history to knowledge, and yet leaves in doubt where it is we have ended up.

How unremarkable, one might say. Did not Charles Olson, in his "Projective Verse" manifesto, reject just this species of poetry as the overwhelming bulk of poetasters showing forth "the-private-soul-at-anypublic-wall" ([24], p. 15)? He did indeed, and in so doing, he attempted to cut his "projective verse" off from one of the most enduring and formidable intellectual and artistic traditions we have, that of the meditative lyric. In the hope of breaking with certain formal conventions that they found stale, post-modern poets such as Olson surrendered a discipline whose history merits recounting herea discipline, again, which Bishop's work exemplifies and develops in such a way as to win her not only a lasting readership but one that includes many Christian scholars and writers.

Like Olson, Bishop would criticize the therapeutic version of the meditative lyric, which Lowell and Berryman were popularizing under the rubric of "confessional verse." She did so, however, not in order to collapse the interiority of lyric, but to insist upon moral discipline rather than an indulgent self-dramatization as central to its achievement. "You just wish they'd keep some of these things to themselves," she would conclude about the confessionals ([12], p. 48). Repelled by the exaggerated "morbidity" ([12], p. 48) of their candor, Bishop came to identify more with the early modernists, whose impersonal lyrics operated with a far greater historical vision and more ambitious moral framework ([5], p. 9). Like the T.S. Eliot of "Tradition and the Individual Talent," she would view the restraint of the lyric of meditation as a means to understanding-including self-understanding-rather than as an offspring of unrestrained self-exposure ([5], pp. 15-16). It is this vision that lends her work its deep continuity with the lyric of meditation as I shall define it-especially the devotional lyrics of the seventeenth century ([5], p. 2) -and also with the literary theory of Winters, which we 
shall see understood the short poem as a technique of contemplation and moral understanding that, while not necessarily devotional, clearly saw an orientation to the divine, however ambivalent or implicit, as essential to itself.

\section{The Meditative Lyric in the Christian-Platonist Tradition}

Bishop's readers have long considered her work to participate in a tradition, beginning with early imagism and especially the poetry of William Carlos Williams, one that celebrates an exact eye for things [25]. As I have already suggested, her poems go well beyond careful observation to enter into a mode of moral reflection that consistently discerns within what meets the eye more than the eye itself can see. In this, she may better be situated in the long tradition of the meditative lyric, the main tradition in English poetry-and, indeed, in western lyric poetry writ large—as it was first described by Martz more than half a century ago. I shall provide here a brief sketch of Martz's understanding of the meditative lyric tradition and its sources; as a sketch it will be incomplete and as one specifically of Martz's position it will largely ignore both the development of theories of the meditative lyric that modify or contest his claims as will it pass over with just a few sentences the long historical background in western philosophy, theology, and spirituality that would be necessary to measure the full significance of the tradition Martz identifies. I choose Martz's account of the meditative lyric not because it is the most thorough, or the most historically exhaustive, but rather because the spirit of his inquiry attempted to make connections between poetic practice and the enduring western tradition, stemming from classical pagan and Christian sources, of an anthropology that understands the human person in terms of its having a nonmaterial rational soul ordained to the contemplation of divine, eternal truth.

In both ancient Platonic and later Christian thought, the human person is understood as ordered to and destined for the contemplation of God. Since the appearance of St. Augustine's de Trinitate, the chief account of the psychology of the human person that makes such an ordination possible has been based on the perception of the human being as an imago dei. God is three persons in one nature, Augustine writes, Father, Son, and Holy Spirit. Man is made in God's image, but not in the sense of a physical image. Rather, man's soul is the image of God specifically as spiritual or intellectual. Augustine examines the various "parts" of that indivisible unity that is the human mind and settles upon three distinguishable aspects of it that analogically manifest the absolute triune being of God.

My mind is one, but, in it, I find memory, understanding, and will ([26], pp. 298-99). Everything that is in my mind is in my memory. But my mind is not merely a warehouse of items. Some things that I can call before my mind I know inside-and-out; some things I can reflect upon with lesser clarity; and some things I can see in my memory though they remain, for the moment, impermeable to my reasoning. Therefore, I must have also a power of understanding distinct from memory. What is more, I choose to think about some things, and ignore others; some things, brought before my mind's eye repulse me, while some are so wonderful that they compel me into movement, drawing me hither (the assent of the mind primarily, but also the movement of the whole self toward some end). And so, my mind must also have a will, a capacity to move toward that which the understanding approves in the memory as good.

Augustine's faculty psychology was chiefly descriptive and speculative- -he wanted to account for what we actually experience when we think, and he wanted to resolve in what respect it was true that "God created man in his image" (Genesis 1:27). But it contained a germinal practical dimension that would find elaboration in the Christian spirituality of the coming centuries. Medieval theologians, such as St. Bonaventure, elaborated Augustine's Trinitarian image of the intellect into itineraria, works of theology distilled specifically for purposes of spiritual exercise, guiding the soul on a journey toward union with God [27].

Martz's theory attempted to demonstrate the diffusion of such thinking into the modern age. In the wake of the Protestant Reformation, such techniques for the life of prayer were disseminated beyond the walls of the monasteries in several forms, the most influential of which are The Spiritual 
Exercises (1522-1524) of St. Ignatius of Loyola and St. Francis de Sales' Introduction to the Devout Life $(1609)$ [28,29]. Loyola and de Sales both developed and popularized techniques of meditation and contemplation that drew the speculative achievements of Augustine's psychology into Christian practice. In their distinct but closely related methods, one finds the novice at meditation instructed to begin by putting himself in the presence of God ([29], p. 73). Then, he should summon to the memory a vivid scene or clear doctrinal statement: the image of Christ on the cross at Golgatha, for instance, or that of ourselves lying prostrate on our death beds. This they generally call the "composition of place," and provide points intended to stimulate in the memory a vivid, sensuous imagination ([29], p. 76). Having seen with the interior eye of memory such a scene, the understanding must give it "consideration," reflecting on it to draw truths from it ([29], p. 77). And, subsequently, the novice is to reorder or conform his will to that understanding in "affection and resolution" ([29], p. 77). This procession from memory to understanding to will concludes in different ways, depending on the spiritual authority. For Francis, we may offer final thanks or confession to God, followed by a spiritual bouquet ([29], pp. 41-61). For Ignatius, the meditation concludes in a kind of interior dramatization called the colloquy ([28], pp. 138, 140). Here, the mind turns to another interior to itself so that it can undertake dialectic and arrive at truth. This may consist of parts of the mind addressing one another or it may involve direct, interior speech with Christ himself.

While the modern lyric tradition that begins in the renaissance has several origins and attributes, this tripartite form of prayerful meditation-imagining a scene (memory), reflecting on its significance (understanding), and reordering the affections (will) accordingly-is perhaps the most universal and conspicuous. It gives shape or otherwise informs most of the short poems that have been written since the beginning of the modern age. And with good reason, for such a structure is at once logical and versatile. It roots the mind in the concrete, but also provides space for the roving intellect and the movements of the will to come to terms with the most individuated reality. It allows the personal to be seen, by way of reflection, in light of the universal, and the immanent in the context of the transcendent. Further, it seems to acknowledge what Augustine tells us is an essential human need, not only to understand ourselves but to judge such truths as we perceive in the scales of goodness. However conventional its movements may appear in the abstract-compose the place, reflect, resolve-Augustine was correct that they conform to, and inform, the natural inclinations of the human soul.

Martz's study draws on the archive of early medieval and early-modern popular works of spirituality, rhetoric, and logic, to show that the faculty psychology it articulates gives birth to the self-dramatizing meditative lyrics of the late renaissance. His later work would suggest that the meditative form is not a genre or a single historical phenomenon, but a generally available set of conventions that makes possible a rich body of lyric poems. Although he never fully resolved the scope of his claims, his work seems to suggest this meditative form influences poets otherwise ignorant of Christian spiritual practices precisely because they already—we already—share in the fundamental anthropological premises that make rational, prayerful, and poetic reflection a source of insight about ourselves and the truth as a whole. Such conventional practices, he writes,

satisfied and developed a natural, fundamental tendency of the human mind-a tendency to work from a particular situation, through analysis of that situation, and finally to some sort of resolution of the problems which the situation has presented. ([11], p. 39)

For this reason, I claimed that Olson's rejection of the meditative lyric was more than just one of laying by exhausted artistic conventions, and that Bishop, in criticizing the confessional poets was in fact defending a valuable inheritance. The meditative lyric lends systematic form to self-scrutiny such that it becomes a contemplation of the life, order, and destiny of the soul. The conventions of confessional poetry often-though not always-reduce the study of the soul to a fragmentary exercise in self-exposure, wherein not the structure and destiny of the soul but the mere content of the contingently formed self becomes the true object of interest. In contrast, the theological faculty psychology that gave rise to the meditative lyric as a medium for knowing and loving God tends to 
give to the poem a depth that may be understood as a moral dimension (regarding the state of the soul) that is finally rooted in a more or less implicit theology (the divine as source and standard of our moral self-understanding). For this reason, Bishop's embrace of the meditative lyric not only leads her poems to exceed the comparatively "secular" poetry of the eye but to remain ambiguously but compellingly open to the supernatural order of God's grace that gives form and meaning to our natural experience. Her Christian readers have sensed this-perhaps more than Bishop did herself.

\section{Bishop's Meditations in a Secular Age}

If the poetry of meditation is so natural, ubiquitous, enduring, and capacious, one may reasonably wonder how it helps us distinguish Bishop's work from that of any other poet. If one may find traces of the Christian techniques of meditation in all poetry that has not, as in the case of Olson, attempted violently to break with them as if they were falsifying and oppressive, then why should Christian readers and scholars so frequently repair to Bishop as a subject of enthusiasm and study?

Not, of course, because Bishop was herself a Christian. "I have never been religious in any formal way and I am not a believer," she wrote to Ann Stevenson in 1964. "I dislike the didacticism, not to say the condescension, of the practicing Christians I know...They usually seem more or less on the way to being fascists." But she continues: "I enjoy reading, say, St. Theresa, very much, and Kierkegaard" ([18], p. 861). St. Theresa of Avila towers among the early modern teachers of meditative prayer and the devout life; Kierkegaard, not incidentally, was the Christian thinker who most compellingly reconfigured, for the modern imagination, the focus of the soul's search for salvation and peace in God to its grappling with the fact of its own existence. Much of the possibility of the meditative lyric lies in nuce within their works.

Bishop was not evidently well versed in the broader Christian spiritual tradition, but she read selectively and with devotion. More than twenty years earlier (1942), she replied to a letter from Marianne Moore regarding some books of modern psychology, which emphasized the therapeutic purpose of the life of the mind all for the end of "self-adjustment" in a secular society. Bishop observed, "I had infinitely rather approach such things from the Christian viewpoint myself-the trouble is I've never been able to find the books, except Herbert" ([18], p. 752). In such a terse statement lies a rich distinction. Bishop was an unbelieving intellectual in a self-consciously secular age; elsewhere in her letter to Stevenson, she expressed the typical liberal pieties one might expect of a Vassar-educated, cosmopolitan poet in the nineteen-sixties. ${ }^{8}$ Product of her time though she was, she saw that its supposed attentiveness to the nuances of the inner life, as exemplified by the rise of modern psychoanalysis, did not necessarily mean the secular age had found a superior means to self-knowledge and contemplation than that found in the Christian tradition. With its therapeutic aims, modern psychology was genuinely "secular," concerned only with the adjustment of the self's immanent experience. The Christianity she cannot embrace insisted, to the contrary, that moral life involved a conformity of the self to an order that transcends all things, the soul as image of God must be healed and purified precisely as image.

It comes as no surprise, then, to see that Bishop's favorite poets included Gerard Manley Hopkins, Charles Baudelaire, Emily Dickinson, and especially George Herbert ([18], p. 703). All these poets, save Baudelaire, are known for what Bishop would call a "use of homely images and...solidity" ([18], p. 690), that is, an attention to the peculiarities of the concrete that finds expression in a peculiarity of phrasing. One of Bishop's writings on Marianne Moore consists of a catalogue of such phrases, demonstrating how "concrete" phrasing draws forth concrete images in the memory ([18], pp. 729-30). S.T. Coleridge

8 On Bishop's contemptuous remarks regarding Christians—-after she says they are on the way to being "fascists", she notes, "I am appalled by the Catholicism, or lack of it, in this Catholic country [Brazil]," and then makes the ostensibly generous concession, "there have been some good Christians!" ([18], pp. 861-62)-Walker justly comments, "one sometimes feels that she doth protest too much" ([4], p. 19). 
and T.S. Eliot both particularly prized Herbert for such imagery, offering these lines as striking in their homely and modest use of metaphor:

And now in age I bud again,

After so many deaths I live and write;

I once more smell the dew and rain,

And relish versing...([30], p. 162)

The poets of Coleridge's age would have yet again mounted the winged horse, or heard the Aeolian harp; how honest and humble for a poet simply to state that he has come once more to "relish versing" ([31], p. 368).

Of these writers, all but Baudelaire was an expressly Christian devotional poet. Martz has argued that Herbert drew directly on the Introduction of Francis de Sales ([11], pp. 249-59), while Hopkins' journals show that the notes he took while making his retreats (during which the Jesuits and their charges undertake Loyola's spiritual exercises) were funneled directly into the lines of his poems. And, in Bishop's day, Eliot's interpretation of Baudelaire as a Christian in tendency-owing as much to the self-lacerating contemplation of the mystery of evil in Joseph de Maistre's Les Soirées de St. Pétersbourg (1821) as he did to the fortuitous novelty of the modern city-was contested but widespread ([32], pp. 337-38). To invoke Baudelaire was to conjure thoughts of moral and religious seriousness in a decadent age. As importantly, all four wrote meditative lyrics in which the movement between the concrete image and the moral understanding is especially obvious. In particular, Herbert's constant self-scrutiny regarding his sinfulness, his forgetful "unkindness" to God, and his miserable waiting for the rewards of salvation that seem almost infinitely deferred, was Bishop's companion, she wrote, "almost all my life" ([18], p. 861).

On the whole, Bishop absorbed the formal structures and thematic emphases of their poems more than she did their phrasing (which owes much to Moore). In this respect, she stands athwart the practice of many of her and our contemporaries, who often indulge in the Celtic alliteration, syntactical play, and eccentric rhyme of Hopkins and Dickinson without retaining the more substantive features of their poetry. Moreover, she embraces these structures in the context of her own agnostic sensibility. By this, I mean two things. Herbert's scrutiny about the state of his soul in service to God is loosened to a general practice of moral reflection. His insistent devotion is rendered a silent, unbelieving openness to the unnamed divinity that subtends that moral reflection.

S.T. Coleridge once reflected, in his notebooks, on the unpopularity of George Herbert in modern times and drew a conclusion relevant to Bishop's practice. Herbert's book of poems had been reprinted many times in the seventeenth century, Coleridge observed, but had ceased to be much admired thereafter. Coleridge had not himself thought much of Herbert in his youth, but had later come to cherish the poems of The Temple. "I cannot avoid drawing the conclusion," noted Coleridge, "there must have been more religious experience, more serious interest in the Christian Faith as a business-like Concern of each Individual [in Herbert's day], than there is at present" ([31], p. 556). In 1826, the intelligent cared at most for the broad general truths of religion, but "When a man begins to be interested in detail, from hour to hour, \& feels Christianity as a Life, a Growth, a Pilgrimage thro' a hostile Country," then he will come to love Herbert's work ([31], p. 556). T.S. Eliot displayed a similar growth in appreciation for Herbert: the essays written during the decade after his conversion to Anglo-Catholicism acknowledge Herbert, but relegate him to the "minor" domain of "devotional" poetry ([33], p. 98). And yet, Eliot's last published work was a mundane but adoring pamphlet on the poet and priest, whose lyrics had taken central place in Eliot's affections (a shift perhaps anticipated by the allusion to Herbert in Eliot's Little Gidding (1942) [34].

All evidence indicates that Bishop descried the moral seriousness in Herbert amid the homely and solid phrases from the beginning. Despite her inability to share in the Christian beliefs of her favorite poets, she sensed that those beliefs had made possible a marvelous technique of introspection and moral analysis. Herbert's poems offer meditations on the sufferings of Christ, and our guilt in 
those sufferings as we re-crucify the Lord with our every petty sin. Further, they detail the Christian's anguish at spoiled worldly expectations, at unfulfilled desires to pray with confidence and joy in this world, and to be sanctified in the next. The experience of these specific and scrupulous forms of guilt and worry were no more likely to be the object of Bishop's concerns than they were of the young Coleridge. But that need not render the meditative journey to God in Herbert's poems sterile for Bishop. She would write to the Herbert scholar, Joseph H. Summers, about his book on the poet, commenting,

How well he understands how really concerned Herbert was with all those insoluble and endlessly nagging problems of man's relationship to God, he is undoubtedly concerned himself. It is real.-It was real and it has kept on being and it always will be...([13], pp. 53-54)

What concerns Herbert is no less "real" because the unbeliever denies the existence of the God Herbert fails to love as he would, but it is also no less real, because what concerns the faithful divine also concerns Bishop. Herbert's anguish is primarily soteriological-he worries whether he has been saved by God and how he has responded to that salvation-but one hears Bishop transfer that anguish to an epistemic plane: her poems mark an effort to "hear," denote, and respond to the significance of things. How things can signify in themselves she does not resolve, but she presents to us a mind in inquiry that does hear-does sound the depths of thing-without explaining why.

What are we to make of this likeness in difference between Bishop and Herbert? Bishop, we have seen, had what we may call the usual prejudices of a secular citizen of a secular age, but does this entail that her account of why Herbert's poetry is "real" to her is best understood as a secularized moral analogue to Herbert's Christian soteriological worries? I think we finally have to answer no, and for reasons we touched on in first mentioning Winters's poetic theory above.

Writing in the nineteen-thirties about the work of Herbert and the deterministic materialist poet, Thomas Hardy, Winters observed that

We have in both poets a common moral territory which is far greater than are the theological regions which they do not share; for, on the one hand, the fundamental concepts of morality are common to intelligent men regardless of theological orientation, except in so far as morality may be simply denied or ignored, and, on the other hand, the Absolute is in its nature inscrutable and offers little material for speculation. It would be difficult, I think, to find a devotional poem of which most of the implications were not moral and universal. ([16], p. 27)

Herbert's poems, according to Winters, may have been rooted in Christian devotion and have taken the salvation of the soul in Christ for subject, but they always speak from the side of our shared human experience as uncertain, reflective, and rational animals in search of the truth to whose light we ought to conform our wills. These "moral and universal" concerns in Herbert's work should not, therefore, be alien to the non-Christian, even as the non-Christian will by definition refuse the name-Christ, our Lord-that guides Herbert's reflections. The presumption of this common terrain on the side of immanence is something Winters shares with Martz. Both presume we are by nature ordered to inquiry into the truth about our souls for the sake of their happiness or fulfillment, that is, their moral life. This is a presumption Augustine also made, in The City of God, when he identified a deep commonality between ancient philosophers and contemporary Christians insofar as both were seeking to discover what was the good or happy life for the human person ([35], 19.1). One wonders how specific one could be regarding "the fundamental concepts of morality" held in common by all "intelligent men", and yet there must surely be some such commonality. The harder claim to grant is that the "Absolute" should be "inscrutable" and therefore does not itself disclose any content that would transform our "fundamental" morality. (We shall turn to that presently.)

Bishop's work demonstrates that Herbert's method of reflection is, as Winters suggests, eminently adaptable to any poet concerned with the moral and the universal, in which all the intelligent share, even if that poet's soul is not ordered by Christian belief and pressing toward fulfillment in religious 
devotion. Winters's favorite poem of Herbert's was "Church Monuments," a meditation on the clay and dust of our mortal substance, and whose finitude we must contemplate and understand, regardless of what becomes of the soul upon the death of the body. The non-Christian Winters would imitate its theme and procedure in several poems written over the span of many years, and would do so in a way that emphasized the universality of Herbert's moral concerns by leaving ambiguous whether the "Absolute" his poetry addresses was the living God or the blank finality of death. ${ }^{9}$

So far, this sounds "secular" par excellence. Winters affirms Herbert as a model poet insofar as he and Hardy share in the immanent moral terrain whose horizon is our death. When he writes, "the Absolute is in its nature inscrutable and offers little material for speculation," it sounds as though Winters were proclaiming the Absolute-his name for God—an "irrelevance," because it will defeat every effort for rational comprehension. One can almost hear a crude rendition of the neo-Thomist philosophers Winters admired echoing in the background that the realm of nature is nature, and that of grace is super-nature, and never the twain shall meet. ${ }^{10}$

But this passage leaves to implication what Winters discusses explicitly elsewhere. In the introduction to In Defense of Reason, he will state that his general intellectual position is that of a moralistic "absolutist" ([16], p. 11). This, he continues, "implies a theistic position" ([16], p. 14). However inscrutable, the Absolute must always be before our minds as a condition of possibility for even our most immanent moral reflections about "absolute truths."11 He is not done. In a later essay on Herman Melville, he will argue that the "relationship of man to the known and to the half known," that is, to the world and the absolute that transcends it, must be explored, or man "will perish of imperception" ([16], p. 202). Poetry not only requires a theistic absolute as a condition of possibility; that absolute, however inscrutable, is itself the fundamental—not to say exclusive-object of poetic contemplation. Poetry can never be secular, because by its nature it requires an openness to the divine in whose light that which is immanent must be understood. For this reason, in the same essay where he praises Herbert and Hardy, he concludes

The conception which I am trying to define is a conception of poetry as a technique of contemplation, of comprehension, a technique which does not eliminate the need of philosophy or of religion, but which, rather, completes and enriches them. ([16], pp. 21-22)

At our every thought, the common moral terrain of the secular world is being informed, and consequently transformed, by the Absolute. As a non-Christian theist, however, Winters cannot specify in what way the substance of that world might be transformed by the deposit of divine revelation. He can only testify that the world of the Christian Herbert seems fundamentally similar to that of the materialist Hardy. Indeed, he goes further. The materialism of Hardy does not cohere with the moral human struggle dramatized in Hardy's poems ([16], p. 27). It would seem therefore that the world of the supposedly secular materialist is itself already transformed by Christianity and, in Hardy, does so simply without acknowledging the source of its moral drama in the absolute. If we are moral, Winters suggests, we are already theistic, we may simply not understand as much, as in the case of Hardy, or-and here we come to the next part of my argument—be willing to say as much, as in the case of Bishop.

If Winters's account is to be trusted, we may judge Bishop's meditative lyrics not as mere secularized analogues to Herbert's. They remain open to the divine- to Christ, to the "Absolute" — both

9 The most revealing such poems are "Inscription for a Graveyard" and "To the Holy Spirit." In the latter poem, Winters specifically terms all that transcends the contemplation of death as an unopened doorway to the Absolute as "irrelevance" ([36], p. 184).

10 I discuss Winters's debt to St. Thomas Aquinas and his modern interpreters in "Representing the Limits of Judgment: Yvor Winters, Emily Dickinson and Religious Experience" [37] and "From Plymouth Rock to Palo Alto: The New England Literary Tradition and Its American Critics" [38] For a basic discussion of the question, see de Lubac, A Brief Catechesis on Nature and Grace [39].

11 See, Powell, Language as Being in the Poetry of Yvor Winters [40]. 
because it grounds them, informs them with moral significance, and, finally, because it is the elusive object of their scrutiny. The difference between the two poets is not that this absolute is real for Herbert but not for Bishop. Rather, one of them can name what is real with the assent of faith, while the other cannot. The moral significance Bishop depicts in her poetry is not a substitute for divine meanings, but a tenuous and uncertain effort to hear and give voice to those meanings in a way that will not upset her jealously guarded "openness". The surprise of epiphany found in "The Fish" and "The Moose" is just that surprise of recognizing an intelligible order woven through the world, while one cannot name its source. The disquisition on knowledge as historical in "At the Fishhouses" suggests there is another kind of knowledge, one that transcends history and its "flowing", that enables us to recognize and judge what we find in history. We think in terms of that knowledge even if we cannot fully justify doing so. We sometimes make clever use of that knowledge—as she does the details of the seal, the fir trees, and the sea-in order to resist the conclusions to which it ought to lead us.

\section{The Burning and the Divided Heart}

Although readers have found several traces of Herbert's language in Bishop's lines, one early poem is closely modeled on Herbert's and testifies in a clear way to Bishop's particular contribution to the tradition of the meditative lyric, which is typified by embrace and resistance, a kind of hearing and an inability to answer [14]. "The Weed," in fact, appears almost as a pastiche of Herbert's "Love Unknown." But these surface similarities make a comparison of the poems especially revealing of a profound commonality of method amid a divergence of assent. The style of Herbert's poem is unusual for him; like "Church Monuments," it is highly enjambed, and so strikes the ear more like blank verse or prose than the closely rhymed iambic pentameter that it is. It begins like a memory to be spun by the fire: "Dear Friend, sit down, the tale is long and sad" ([30], p. 125). But we are soon in the land of allegory; the narrator tells us of his landlord, to whom he brings "a dish of fruit" with his heart in the middle. The servant of the lord no sooner sees the gift than, knowing his master's wish, seizes the heart alone,

And threw it in a font, wherein did fall

A stream of blood, which issu'd from the side

Of a great rock...([30], p. 125)

The interlocutor replies, "Your heart was foul, I fear," and the narrator concurs. But with a clean heart, the narrator finds himself out walking and passes a boiling cauldron, with "AFFLICTION" stamped about its lip ([30], pp. 125-26). The narrator brings some livestock to sacrifice to it, but, in another reversal, "the man / Who was to take it from me, slipt his hand, / And threw my heart into the scalding pan" ([30], p. 126). The interlocutor comments, "Your heart was hard," but the cauldron's heat tenderized it. Exhausted from this boiling, the narrator goes home to find that the one being to whom he had given his key has stuffed the bed with thorns. "Your heart was dull," he is told.

For the narrator, his is but an episodic tale of thwarted expectations and recurrent suffering; he cannot name its meaning. But his listener can. He tells him, "your Master shows to you / More favour than you wot of" and advises that he should "be cheer'd, and praise him to the full" who "would have you be new, tender, quick" ([30], p. 127). On the side of earthly experience, the allegory is one of continued pain, but from the perspective of salvation, it reveals itself to have been a journey of purification through the gifts of repentance, penance, and grace. When we hear a Herbert poem speak of a "Lord," we know beforehand just whom he means, because we know we are reading an allegory. But, here, his narrator does not, and in consequence he cannot interpret that experience he does know. As Martz concludes, by the end we see that Christ the Lord has been with the speaker from the beginning, for it is Christ present in and to the soul (whose life the poem as a whole dramatizes) who addresses him in colloquy and explains him to himself ([11], p. 309).

Bishop picks from Herbert's imagery what she describes as the most "surreal" elements, and appropriately embeds them in the form of a dream rather than an allegory ([18], p. 861). "I dreamed that 
dead, and meditating, I lay upon a grave, or bed," she begins ([18], p. 15). In the frozen, unchanging darkness, she lies, until, "Suddenly there was a motion...A slight young weed/had pushed up through the heart and its / green head was nodding on the breast" ([18], p. 15). She then describes the slow, disturbing growth of this weed as it emerges from her body:

The nervous roots reached to each side; the graceful head changed its position mysteriously, since there was neither sun nor moon to catch its young attention. ([18], p. 16)

And then, the heart begins to change: not beating but splitting apart until two streams of water gush forth. Bishop parenthetically notes that these waters, like those in "At the Fishhouses," bear with them all the reflected knowledge—-the memory—of experience, before she at last addresses the weed:

"What are you doing there?" I asked.

It lifted its head all dripping wet

(with my own thoughts?)

and answered then: "I grow," it said,

"but to divide your heart again." ([18], p. 16)

Rather than following the allegorical method of Herbert's poetry, "The Weed," as a "surreal" dream, suggests why Bishop found modern psychology wanting and so depended upon the strict method and definitively moral reflection found in Herbert and other Christian spiritual writers. For Herbert, and the meditative lyric tradition more generally, the record of experience gathered into the memory makes itself available for recollection, reflection, and understanding. Memory draws the distended minutes of our temporal experience into a unity that we may come to understand and judge morally in the reordering of our will to God. When we understand our experience fully, "Love Unknown" teaches, we discover that our original perspective on it had been inadequate, had been too bogged down by the smarts of suffering. We must come to accept a richer account of it that is capable of seeing the hand of God at work on our souls, preparing us for salvation, and the voice of God speaking already to us. In brief, the steps of meditation gradually gather the multiplicity of experience into a coherent meaning that, in turn, will lead our reformed wills to life in genuine unity with our Lord. But this in turn teaches us that those immanent steps in the world lead beyond it and, finally, reveal their true significance only in the light of Christ.

Bishop's poem tells a seemingly different story, but with a strange affinity to Herbert's. The pierced suffering of our hearts severs us, splitting the unified current of a life into separate, incoherent streams. Experience does not appear to accrue to a unity-that of a single, meaningful life, whose significance can be stated. Experience divides and divides the longer it goes on. It is as if Bishop has replaced the faculty of memory in our souls with the state of trauma in the self, in which broken fragments of suffering simply repeat themselves without issue in the understanding. Most critics agree that the weed represents the power of artistic creativity-the ability to produce a new poem tears the poet's heart in two ([14], p. 77). Walker attests to the disintegrative experience in the poem as akin to Herbert's, because, for both, suffering becomes a blessing ([4], p. 129). But, Corelle underscores, the blessing of "The Weed" is a refusal of Christian belief and a seeking of redemption in the growth suffering in itself brings about ([5], p. 50). Though the poet may suffer, a new poem is brought into being through pain and by her power. These are eminently secular readings of the poem that acknowledge Herbert's influence but which overlook its two most profound elements.

This condition of imprisonment and division is her natural condition, Bishop dreams. Unless she can find a means to bring order to her experience, to hold it together for analysis, she will have not a living soul but a fragmented mass of suffering-a mere "self." And that is just what Herbert and her other favorite poets offer: a means, a method, to make the divisions of the heart cohere. A life that 
would be otherwise inscrutable becomes intelligible, instinct with moral significance. Recall her letter to Moore, cited above. The therapeutic path to "self-adjustment" found in modern psychology cannot give us entry into this sort of understanding, but the devotional methods of Herbert's meditative lyrics, and the psychology or anthropology of what Bishop identifies as the Christian tradition as a whole, can do so. Herbert does not just give her images for her poem, he lends to it a moral form that she can use, lacking any other. Memory recalls the scene, reason enters into it, and the will makes its resolution in response to what has been understood. But if the movement toward understanding is suggested, the poem halts before it has been achieved in a way that contrasts starkly with its source.

It is worth noting that even the title of Bishop's poem signals this partial identification with an older tradition. For Herbert, the purpose of the interior discernment of Christianity was at once the repentance and piety of the parson and the reflection and praise of the poet. In "Employment (1)," crucially, he would observe that "All things are busy; only I / Neither bring honey with the bees, / Nor flowers to make" it ([30], p. 55). Parson and poet in this respect stand outside the world of sweet and brilliant fruitfulness, even to the point of being "no link" in God's "great chain" of being. But then Herbert's gaze returns upon himself and he observes "all my company is a weed," and he asks that God "give one strain / To my poor reed" ([30], p. 55). The poet is a weed, a reed, blown by the wind, reflecting on if not properly participating in the economy of creation. So, in calling her poem "The Weed," Bishop identifies herself with Herbert as country parson (outside of the busy world) and poet, and further cements the relation of her poetry to the long tradition of the Christian meditative lyric. Like Herbert—and like Coleridge and Hopkins, who also allude to "Employment" in their poems - she, as poet, is herself a weed; that is, concerned to sing a "strain" from the modest and otherwise useless reed of the throat regarding the moral significance of the world's chain of being, suspended from the God in whom she does not believe and whom she cannot name.

Here we arrive at the striking tension of the poem. Let us recall that Herbert's poem is an allegory, while Bishop's is a dream. What, as even the modern psychologists she dismissed would admit, is the difference between these two forms? For an allegory to function, we must know the name to which its figures correspond; we must be able to discern them as if in advance, because only once we do have we really read the allegory. In Herbert's, we know the Lord, even if his narrator does not; but we learn something new about that Lord, from his own lips, by the poem's end. Dreams signify, too. They are symbolic, or at least we like to think so, and to know their meaning is, as in the case of allegory, to know what the symbols signify outside the reality of the dream. But a dream does not allow those who "read" it to name the truth behind the symbol in advance and, in fact, the name may remain forever elusive, melting away just when thought turns upon it. Bishop's poem breaks off, with the weed saying what it will do, but not-in contrast to the Herbert poem-what it has done and what its actions mean. Bishop's poem therefore is no less a religious poem of meditation than is Herbert's. It is just one where the ambiguity of dream prevents the poet from naming what it all means, even as Herbert's precedent helps her to put that uninterrupted and as yet incomprehensible experience into an order suitable for meditation. Her dream is not secular-not cut off from the divine-but is in part about the inability to name the god on which its meaning depends and to which reflection attempts in vain to order the soul.

It was Bishop's contribution, therefore, to show that those insensible to, or uninterested in, the "business" of redemption still require the form of the meditative lyric. They need it, first, not to bring their souls to heaven, but to keep their senses from falling apart. The world threatens to disintegrate the soul into unintelligible elements of selfhood, but with patience of observation, she is able to hold the scene in place and cajole it into giving up some of its moral meaning. But there is much that Bishop's poems remain incapable of naming, including the ground and end that give that moral meaning reality in the first place. "The Weed" is distinctive not only because it so closely resembles Herbert's Christian lyric of meditation, but because it underscores, by its "surreal" ambiguity, its inability to name God and to attain even to the anguished faith of Herbert, which knows for whom it suffers. 
The depth and complexity of poems from across Bishop's career becomes more apparent when we view them as wrangling with the Christianity of Herbert and as unfolding in accordance with the conventions of the poetry of meditation. The early "Roosters," generally read as a poem critical of Bishop's childhood Christianity, can be seen, with its playful rhyming triplets, as sounding the depths of the things for their allegorical significance. The literal detail of crowing roosters comes to appear as "the flesh alone," beyond which Bishop's associative, meditative mind passes to the "spirit," that is, the figural and moral significance the roosters themselves reveal ([18], p. 29).

The opening "Brazil" section of Questions of Travel (1965), comes more obviously to appear as a sustained moral meditation. "Arrival at Santos," for instance, provides a wealth of visual detail, offering us all that a "tourist" might see ([18], p. 71), and indeed the poem seems to insist on giving us only the superficial desiderata of a travel log, until in the last two lines we read, "We leave Santos at once; / we are driving to the interior" ([18], p. 72). The subsequent poems are full of exotic and brightly colored surfaces but in each instance support a kind of itinerarium, a journey to the interior whose concerns are often explicitly moral. The first stanza of the next poem "Brazil, 1 January 1502" is consumed by adjectives trying to capture the wild Brazilian foliage. In the second, however, we learn that this lush tropical land is what the early Christian explorers saw and, for them, it was at once an image of alien abundance, a glimpse of the paradise their faith promises, and also a tawdry image of extravagance, of "wealth and luxury" ([18], p. 73). The poem suggests therefore how the startling power of what appears vivid chiefly because it is novel can be morally polysemantic. Just as Bishop took most Christians for "fascists" even as she admired their spiritual achievements, so we see an early moment of colonial conquest interwoven with a foretaste of the soul's paradise. Spiritual depth and the lust for domination both linger as meanings just behind the "silver" surface of things. We could site other poems in the section that operate with similar meditative and moral probing, but it will suffice to mention one more. "The Armadillo," Bishop's poem for her "confessional" and apostate Catholic friend, Robert Lowell, echoes some of his work's shocked disbelief at Catholic credulity regarding the saints, as she describes a fire balloon "rising toward a saint / still honored in these parts" ([18], p. 83). With Lowell, she is alienated from such veneration and finds it arcane and provincial. And yet the beautiful but destructive light of the balloon, as it floats into a cliff and splatters fire over an "ancient owls' nest" proves more than an archaism. It is a spectacular mystery, at once "pretty" and overloaded with spiritual and dreadful associations. Like the tropical foliage of Brazil in the earlier poem, like the scales of herring in "At the Fishhouses," the balloon is both a sign of faith and unbelief, of peace and force.

In the "Elsewhere" section of the same volume, the unusual warmth of style of "Filling Station" turns out not to be curious in style alone. "Oh, but it is dirty!" ([18], p. 123), the poem begins, so that before the poet's attentive eye to empirical detail can tell us of the father wearing "a dirty, / oil-soaked monkey suit / that cuts him under the arms" ([18], p. 123), the moralized voice of the poet has interjected and pushed itself to the fore. Although the poem rivals "The Moose" and "At the Fishhouses" in its notation of literal, sensuous description, this initial emphasis of voice suggests that these details are already subject to perception, interpretation, and judgment, such that the act of determining a moral significance that has already been felt becomes the poem's subject. Such significance will not gradually be earned by the poet's keen eye, but is present from the loaded first syllable. After three stanzas of descriptive declarative sentences, the poem's fifth consists of three questions about "Why" the filling station is appointed as it is, followed by a parenthesis in which Bishop emphasizes her own presence as the interpreter of this scene with the clause, "I think." In the final stanza everything perceptible by the senses is recognized as the outcome of a prior intention:

Somebody embroidered the doily,

Somebody waters the plant, or oils it, maybe. Somebody ([18], p. 124)

The things seen at first seem to defy explanation-everything is so dirty-and yet it is all there for some reason, according to "Somebody's" will and purpose. And if this can be affirmed in such 
a seemingly haphazard and soiled place, then it must be possible to conclude, as the poem does, "Somebody loves us all" ([18], p. 124). Bishop is obviously enough playing with the idea of the God of Love whom Herbert's many poems name and scrutinize with such anguish and apparent sincerity. Most Christian readers will not hesitate to respond to the poem by saying, "Of course, it is God who loves us all," and the poem invites just this response-invites it without offering it or confirming it. "Filling Station" indicates that the real subject of the meditative lyric is the moral significance, the intention, that lies behind, orders, and explains the world as we encounter it; it does so by unmistakably foregrounding the role of the querying perceiver in the poem. But it also refuses to name that apparently ridiculous "Somebody" who could love an existence that seems, at first, oh, so unlovable.

Bishop's "In the Waiting Room" gives us a helpful further example of how the conventions of the meditative lyric transform her practice and rightly inform our interpretation of her work. The short, loosely trimeter lines reminiscent of "The Fish" (discussed above) unfold at a breathless, panicked pace; she tries to recapture the feelings of a young child's naiveté and confusion at seeing naked, foreign bodies in National Geographic, while hearing also her Aunt Consuelo suffer from a dental procedure. As Bishop dramatizes her young self, we hear echoes of "The Weed." She feels alienated from herself, indeed self-divided. Between the poem's voice and its depiction of painful experience, we might conclude with many critics that here Bishop ignores her criticism of confessional poetry and indulges in it. But this seems reductive. As in "The Weed," an anguished act of reflection seeks to overcome the feeling of self-estrangement by reasserting the integrity or unity of her self and soul: "You are an I, / you are an Elizabeth" ([18], p. 150). The result of the mind's reassertion of self-identity is hardly conclusive; it ends only by affirming the need for the assertion in the face of fear, doubt, and anxiety. It was to the Christian Herbert rather than to the confessional Lowell, we might say, that she would look, in this anxiety, for some hope of moral and spiritual order. It nonetheless remains an unrealized hope.

No wonder, then, that Christian readers find Bishop's work congenial. She embraces the poem as a technique of meditation, in continuity with the practice of Herbert and Hopkins, and the more ancient anthropology and practice of the Christian tradition. She does so, even as other modern poets, such as Olson, seem to reject it all in provincial incomprehension. But, further, far from giving us a secularized form of that practice, wherein, as Corelle proposes, the amelioration of art becomes a substitute for redemption in the Church ([5], p. 1), Bishop leaves open the dependence of our immanent experience on the unnamed reality beyond it. Time and again, she affirms a moral presence that remains, in terms of direct perception, an absence and an incompletion. "The Weed" breaks off before the poem can reflect on its own meaning; "Filling Station" concludes on "Somebody" still unnamed; we never learn, in "At the Fishhouses," by what ahistorical knowledge we can justly affirm that all knowledge is merely historical.

It is clear Bishop really did leave these conclusions tenuous, open, and unnamed, too. At the end of her life, she was still scrutinizing and resisting the name of God. She began reading Augustine's The City of God, that keystone text of the Christian account of the soul, the world, and salvation, and in her excitement contacted Peggy Ellsberg, a friend and Hopkins scholar she knew to be a Catholic. "I want to believe this," she told Ellsberg ([5], p. 21), and then she queried her friend as she evidently had queried Herbert over many years. Did she believe it, Bishop wanted to know. That is, was it real for her? Bishop had spent her career close to the heart of the meditative lyric tradition, and so had already the techniques and conventions she needed to pose these questions. However secular her age, she could not lay such questions by. Although Olson and the confessionals had already adumbrated two different paths of post-Christian poetics (one that dismissed the soul out of hand, the other which made of it a fragmentary formless self to be exposed but never to be understood), she took another way. What she lacked —and seems to have lacked all the way through to the end-was the ability to answer, as Herbert most finally answered, "My Lord" ([30], p. 150).

Conflicts of Interest: The author declares no conflict of interest. 


\section{References}

1. Gioia, Dana. The Catholic Writer Today. Milwaukee: Wiseblood Books, 2014.

2. Gioia, Dana. “The Example of Elizabeth Bishop.” In Can Poetry Matter? Saint Paul: Graywolf Press, 2002, pp. 215-20.

3. Gioia, Dana. “Elizabeth Bishop: From Coterie to Canon.” In Disappearing Ink. Saint Paul: Graywolf Press, 2004, pp. 185-99.

4. Walker, Cheryl. God and Elizabeth Bishop: Meditations on Religion and Poetry. New York: Palgrave MacMillan, 2005.

5. Corelle, Laurel Snow. A Poet's High Argument: Elizabeth Bishop and Christianity. Columbia: University of South Carolina Press, 2008.

6. New, Elisa. "Awe, Wonder, and Wit: Elizabeth Bishop and the Modernization of Calvinist Mood." In The Calvinist Roots of the Modern Era. Edited by Aliki Barnstone, Michael Tomasek Manson and Carol J. Singley. Hanover: University Press of New England, 1997, pp. 107-24.

7. Mariani, Paul. Lost Puritan: A Life of Robert Lowell. New York: W.W. Norton and Co., 1994.

8. Mariani, Paul. Dream Song: The Life of John Berryman. San Antonio: Texas University Press, 1990.

9. Wilson, James Matthew. The Catholic Imagination in Modern American Poetry. Milwaukee: Wiseblood Books, 2014.

10. Wilson, James Matthew. The Fortunes of Poetry in an Age of Unmaking. Milwaukee: Wiseblood Books, 2015.

11. Martz, Louis L. The Poetry of Meditation. New Haven: Yale University Press, 1954.

12. Millier, Brett Candlish. "Modesty and Morality: George Herbert, Gerard Manley Hopkins, and Elizabeth Bishop." The Kenyon Review 11 (1989): 47-56.

13. Summers, Joseph H. "George Herbert and Elizabeth Bishop." George Herbert Journal 18 (1995): 48-58. [CrossRef]

14. Powers-Beck, Jeffrey. “Time to Plant Tears': Elizabeth Bishop's Seminary of Tears." South Atlantic Review 60 (1995): 69-87. [CrossRef]

15. Lafford, Erin. “Elizabeth Bishop's 'Dappled Thing': Visual Counterpoint and Devotional Attention in 'The Man-Moth'." Literature and Theology 25 (2011): 252-67. [CrossRef]

16. Winters, Yvor. In Defense of Reason. Athens: Swallow Press, 1987.

17. Brague, Rémi. “The Impossibility of a Secular Society." First Things 236 (2013): 27-31.

18. Bishop, Elizabeth. Poems, Prose, and Letters. New York: The Library of America, 2008.

19. Wilson, James Matthew. “The Realism of Helen Pinkerton." Christianity and Literature 58 (2009): 629-52. [CrossRef]

20. Wilson, James Matthew. "Brian Coffey, Jacques Maritain, and the Recovery of the "Thing'." In The Maritain Factor: Taking Religion into Interwar Modernism. Kadoc-Studies on Culture, Religion and Society; Edited by Rajesh Heynickx and Jan De Maeyer. Leuven: Leuven University Press, 2010, pp. 138-51.

21. Hume, David. A Treatise on Human Nature. Mineola: Dover, 2003.

22. Jenkins, Iredell. “The Postulate of an Impoverished Reality." The Journal of Philosophy 39 (1942): $533-47$. [CrossRef]

23. Schindler, D.C. The Catholicity of Reason. Grand Rapids: Wm. B. Eerdmans, 2013.

24. Olson, Charles. Selected Writings. New York: New Directions, 1967.

25. Ricks, Christopher. Reviewery. New York: Handsel Books, 2001.

26. Augustine. The Trinity. Translated by Edmund Hill. Hyde Park: New City Press, 2005.

27. Bonaventure. The Soul's Journey into God; The Tree of Life; The Life of Francis. Translated by Ewart Cousins. Mahwah: Paulist Press, 1978.

28. Ignatius of Loyola. Spiritual Exercises and Selected Works. Edited by George E. Ganss. New York: Paulist Press, 1991.

29. De Sales, Francis. Introduction to the Devout Life. Translated by John K. Ryan. New York: Image Books, 1989.

30. Herbert, George. The Complete English Works. Edited by Ann Pasternak Slater. New York: Everyman's Library, 1995.

31. Coleridge, Samuel Taylor. The Major Works. Oxford: Oxford University Press, 2000.

32. Eliot, Thomas Stearns. Selected Essays 1917-1932. New York: Harcourt, Brace and Co., 1932.

33. Eliot, Thomas Stearns. Essays Ancient and Modern. New York: Harcourt, Brace and Company, 1936.

34. Eliot, Thomas Stearns. George Herbert. London: Longmans, Green, and Co., 1962.

35. Augustine. The City of God against the Pagans. Translated by R. W. Dyson. Cambridge: Cambridge University Press, 1998. 
36. Winters, Yvor. Collected Poems. Chicago: Swallow Press, 1978.

37. Wilson, James Matthew. "Representing the Limits of Judgment: Yvor Winters, Emily Dickinson and Religious Experience." Christianity and Literature 56 (2007): 397-22. [CrossRef]

38. Wilson, James Matthew. "From Plymouth Rock to Palo Alto: The New England Literary Tradition and Its American Critics." Christianity and Literature 64 (2015): 82-110. [CrossRef]

39. De Lubac, Henri. A Brief Catechesis on Nature and Grace. Translated by Richard Arnandez. San Francisco: Ignatius Press, 1984.

40. Powell, Grosvenor. Language as Being in the Poetry of Yvor Winters. Baton Rouge: Louisiana State University Press, 1980.

(C) 2017 by the author; licensee MDPI, Basel, Switzerland. This article is an open access article distributed under the terms and conditions of the Creative Commons Attribution (CC-BY) license (http://creativecommons.org/licenses/by/4.0/). 